\title{
The Effect of Bornyl cis-4-Hydroxycinnamate on Melanoma Cell Apoptosis Is Associated with Mitochondrial Dysfunction and Endoplasmic Reticulum Stress
}

\author{
Tzu-Yen Yang ${ }^{1}$, Yu-Jen $\mathrm{Wu}^{2,3}$, Chi-I Chang ${ }^{4}$, Chien-Chih Chiu ${ }^{5}$ ib and Mei-Li Wu ${ }^{1, *}$ \\ 1 Department of Food Science, National Pingtung University of Science and Technology, \\ Pingtung 91202, Taiwan; gini0307@yahoo.com.tw \\ 2 Department of Beauty Science, Meiho University, Pingtung 91202, Taiwan; x00002180@meiho.edu.tw \\ 3 Department of Biological Science and Technology, Meiho University, Pingtung 91202, Taiwan \\ 4 Department of Biological Science and Technology, National Pingtung University of Science and Technology, \\ Pingtung 91201, Taiwan; changchii@mail.npust.edu.tw \\ 5 Department of Biotechnology, Kaohsiung Medical University, Kaohsiung 80708, Taiwan; \\ woodnettle2002@gmail.com \\ * Correspondence: mlwu@mail.npust.edu.tw; Tel: +886-8-7703202 (ext. 7064); Fax: +886-8-7740378
}

Received: 6 April 2018; Accepted: 28 April 2018; Published: 4 May 2018

\begin{abstract}
Bornyl cis-4-hydroxycinnamate, an active compound isolated from Piper betle stems, was investigated in terms of its effects on A2058 and A375 melanoma cell proliferation and protein expression in this study. We used flow cytometric analysis to examine the early stages of apoptosis induced by bornyl cis-4-hydroxycinnamate in the two melanoma cell lines and employed comparative proteomic analysis to investigate the effects of this compound on protein expression in A375 cells. Master maps generated by PDQuest software from two-dimensional electrophoresis (2-DE) analysis of A375 cells showed that the expression levels of 35 proteins were significantly altered, with 18 proteins upregulated and 17 downregulated. The proteomics study identified several proteins that are involved in mitochondrial dysfunction and endoplasmic reticulum stress (ER stress), in addition to apoptosis-associated proteins, including prohibitin, hypoxia-upregulated protein 1, stress 70 protein, $78 \mathrm{kDa}$ glucose-regulated protein (GRP78), and protein deglycase DJ-1 (protein DJ-1) in melanoma cells exposed to bornyl cis-4-hydroxycinnamate. The treatment also resulted in a marked decline of the mitochondrial membrane potential, in cytochrome $C$ release into the cytosol, in the activation of Bcl-2-associated $\mathrm{X}$ protein (Bax), Bcl-2-associated death promoter protein (Bad), caspase-3, and caspase-9, and in the decreased expression of p-Bad, B-cell lymphoma 2 (Bcl-2), Bcl-xl, and induced myeloid leukemia cell differentiation protein-1 (Mcl-1), indicating that apoptosis induced by bornyl cis-4-hydroxycinnamate was mediated by the mitochondria through the caspase-dependent pathway. Also, salubrinal (an eukaryotic initiation factor $2 \alpha$ inhibitor; eIF $2 \alpha$ inhibitor) was able to protect the cells from bornyl cis-4-hydroxycinnamate-induced apoptosis. Bornyl cis-4-hydroxycinnamate-related cell death also implied that the protein kinase R-like endoplasmic reticulum kinase (PERK)-eIF2 $\alpha$-ATF4-CHOP signal pathways was activated upon bornyl cis-4-hydroxycinnamate treatment. Altogether, our results support the conclusion that bornyl cis-4-hydroxycinnamate-induced apoptosis in melanoma cells is associated with mechanisms correlated with the activation of caspase cascades, mitochondrial dysfunction, and endoplasmic reticulum stress, and indicate that this molecule has the potential to be developed as a chemotherapeutic agent for human melanoma.
\end{abstract}

Keywords: melanoma; bornyl cis-4-hydroxycinnamate; proteomic; mitochondrial dysfunction; apoptosis; endoplasmic reticulum stress 


\section{Introduction}

Melanoma has a relatively low incidence among skin cancers, but also causes the vast majority of skin cancer deaths. In addition, the incidence rates of melanoma worldwide continue to rise rapidly [1]. In 2017, the American Cancer Society estimated that more than 87,000 new melanomas would be diagnosed in the US and approximately 10,000 people would die of melanoma that year [2]. The majority of patients with metastatic melanoma are almost invariably incurable because no effective chemotherapy or immunotherapy are available [3-5]. Therefore, currently, surgical resection alone or in combination with other therapies is still the best option to prolong the survival of patients $[6,7]$. Despite the great numbers of studies and clinical trials that have been performed in recent decades, dacarbazine, the most active single agent against melanoma, can only achieve an approximate $20 \%$ objective response rate [8,9], and interleukin (IL)-2 therapy only produces a response rate below $20 \%[10,11]$. Therefore, the development of novel drugs and therapeutic approaches for malignant melanoma is an urgent medical issue.

Piper betle Linn. (Piperaceae), known as the betel vine, is a perennial semi-woody climber with a strong pungent and aromatic flavor that grows widely in Southeast Asia. It is an important medicinal and economical plant in some Asian countries, such as Taiwan and India, and has been proven to exhibit antioxidative, antimicrobial, and anti-hemolytic activities [12-14]. Several bioactive constituents such as lignins, polyphenols, alkaloids, steroids, saponins, tannins, and terpenes have been isolated from the leaves and stems of $P$. betle [15]. Bornyl cis-4-hydroxycinnamate is an active compound isolated from $P$. betle stem. In this study, we investigated the effects of bornyl cis-4-hydroxycinnamate on the proliferation of melanoma cells and employed a comparative proteomics approach to identify the molecules involved in bornyl cis-4-hydroxycinnamate-induced apoptosis in A2058 and A375 melanoma cells. We aimed to ascertain the underlying mechanism, which may lead to the development of bornyl cis-4-hydroxycinnamate as a new treatment agent or a potential strategy against human melanoma.

\section{Results}

\subsection{Characterization of the Constituents of the Ethyl Acetate (EA) Fraction of P. betle Stems}

One monoterpene, bornyl cis-4-hydroxycinnamate, was afforded from the ethyl acetate fraction of $P$. betle stems, and its chemical structure was confirmed by comparing its physical and spectral data (specific rotation, mass spectrometry (MS), and nuclear magnetic resonance (NMR) spectroscopy) with the values described in the literature [16]. Bornyl cis-4-hydroxycinnamate (Figure 1): amorphous white powder; $[\alpha]^{27} \mathrm{D}=+16.1^{\circ}\left(\mathrm{c} 0.5, \mathrm{CHCl}_{3}\right) ;{ }^{1} \mathrm{H}-\mathrm{NMR}\left(400 \mathrm{MHz}, \mathrm{CDCl}_{3}\right) \delta 0.84\left(3 \mathrm{H}, \mathrm{s}, \mathrm{H}-10^{\prime}\right)$, $0.86\left(3 \mathrm{H}, \mathrm{s}, \mathrm{H}-8^{\prime}\right), 0.91\left(3 \mathrm{H}, \mathrm{s}, \mathrm{H}-9^{\prime}\right), 1.03\left(1 \mathrm{H}, \mathrm{dd}, J=13.6,3.2 \mathrm{~Hz}, \mathrm{H}-3^{\prime} \mathrm{b}\right), 1.19\left(1 \mathrm{H}, \mathrm{m}, \mathrm{H}-5^{\prime} \mathrm{b}\right)$, $1.24\left(1 \mathrm{H}, \mathrm{m}, \mathrm{H}-6^{\prime} \mathrm{b}\right), 1.67\left(1 \mathrm{H}, \mathrm{t}, J=4.4 \mathrm{~Hz}, \mathrm{H}-4^{\prime}\right), 1.72\left(1 \mathrm{H}, \mathrm{m}, \mathrm{H}-5^{\prime} \mathrm{a}\right), 1.87\left(1 \mathrm{H}, \mathrm{m}, \mathrm{H}-6^{\prime} \mathrm{a}\right)$, $2.41\left(1 \mathrm{H}, \mathrm{m}, \mathrm{H}-3^{\prime} \mathrm{a}\right), 4.90\left(1 \mathrm{H}, \mathrm{br} \mathrm{d}, J=10 \mathrm{~Hz}, \mathrm{H}-2^{\prime}\right), 5.85(1 \mathrm{H}, \mathrm{d}, J=12.8 \mathrm{~Hz}, \mathrm{H}-2), 6.74(2 \mathrm{H}, \mathrm{d}, J=8.4 \mathrm{~Hz}$, H-6, H-8), $6.85(1 \mathrm{H}, \mathrm{d}, J=12.8 \mathrm{~Hz}, \mathrm{H}-3), 7.53(2 \mathrm{H}, \mathrm{d}, J=8.8 \mathrm{~Hz}, \mathrm{H}-5, \mathrm{H}-9) ;{ }^{13} \mathrm{C}-\mathrm{NMR}\left(\mathrm{CDCl}_{3}\right)$ ঠ: $13.5\left(\mathrm{C}-10^{\prime}\right), 18.7\left(\mathrm{C}-9^{\prime}\right), 19.6\left(\mathrm{C}-8^{\prime}\right), 27.0\left(\mathrm{C}-6^{\prime}\right), 27.9\left(\mathrm{C}-5^{\prime}\right), 36.6\left(\mathrm{C}-3^{\prime}\right), 44.8\left(\mathrm{C}-4^{\prime}\right), 47.7\left(\mathrm{C}-7^{\prime}\right)$, $48.7\left(\mathrm{C}-1^{\prime}\right), 80.4\left(\mathrm{C}-2^{\prime}\right), 115.2$ (C-6, C-8), 117.0 (C-2), 126.8 (C-4), 132.0 (C-5, C-9), 144.0 (C-3), 157.3 (C-7), 168.0 (C-1); infrared spectroscopy (IR) (KBr) $v_{\max }: 3370,1685,1605,1515,1155 \mathrm{~cm}^{-1}$; electron-impact (EI) MS (70 eV) $m / z$ (relative intensity) $300[\mathrm{M}]^{+}$(10), 164 (5), 147 (100), 136 (3), 119 (20), 91 (15), 81 (6), 69 (3), 55 (4). NMR spectroscopy and mass spectrometry (MS).

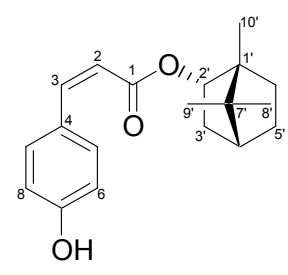

Figure 1. Chemical structure of bornyl cis-4-hydroxycinnamate isolated from the stem of Piper betle. 


\subsection{Cytotoxic and Antiproliferative Effects of Bornyl cis-4-Hydroxycinnamate on Melanoma Cells}

To examine the potential cytotoxic effects of bornyl cis-4-hydroxycinnamate on melanoma cells (A2058 and A375 cells), 3-(4,5-Dimethylthiazol-2-yl)-2,5-diphenyltetrazolium bromide (MTT) assays and analyses of the morphological changes were performed. The cytotoxic effect of various concentrations of bornyl cis-4-hydroxycinnamate $(3,6,9,12,15$, and $18 \mu \mathrm{M})$ on A2058 and A375 melanoma cells was examined, and the results of the MTT assays revealed that bornyl cis-4-hydroxycinnamate reduced the proliferation of the two melanoma cell lines in a concentration-dependent manner (Figure 2A). With $12 \mu \mathrm{M}$ bornyl cis-4-hydroxycinnamate treatment, the cell number of A2058 and A375 cells was significantly reduced (Figure 2B).

A

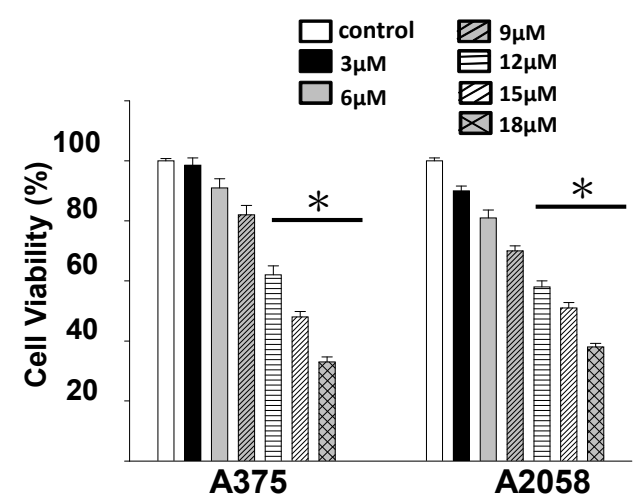

B

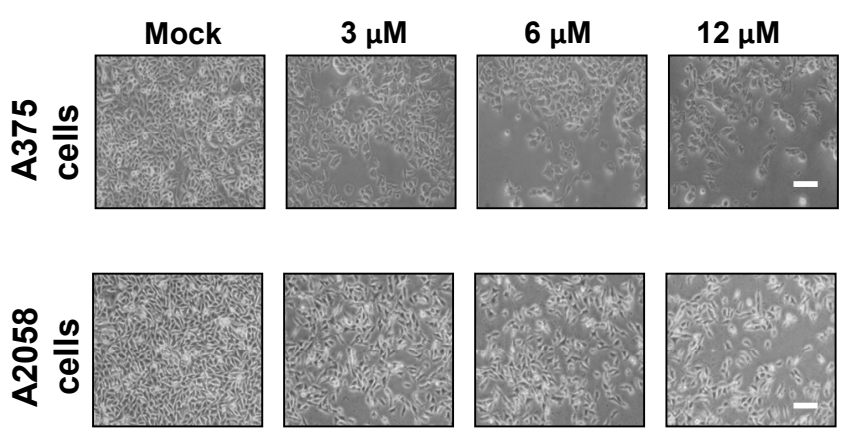

Figure 2. Evaluation of the cytotoxic and antiproliferative effects of bornyl cis-4-hydroxycinnamate on melanoma cells. (A) The cell viability of melanoma cells (A2058 and A375 cells) was inhibited in a concentration-dependent manner, as observed by MTT assay. Data are presented as mean \pm SD. of at least three experiments independently. The results were analyzed with the statistical approach Student's $t$-test ( ${ }^{*} p<0.001$, compared with the control). (B) Morphological changes and reduced cell populations of A2058 and A375 melanoma cells treated with different concentrations of bornyl cis-4-hydroxycinnamate (3, 6, and $12 \mu \mathrm{M})$. Scale bar: $50 \mu \mathrm{m}$.

\subsection{Apoptosis Is Triggered by Bornyl cis-4-Hydroxycinnamate in Melanoma Cells}

Figure 2 shows that bornyl cis-4-hydroxycinnamate inhibited A2058 and A375 cell proliferation in a concentration-dependent manner. Apoptotic assays were then performed to investigate whether bornyl cis-4-hydroxycinnamate also induced melanoma cell apoptosis. After exposure to bornyl cis-4-hydroxycinnamate, flow cytometry analysis of annexin V-fluorescein isothiocyanate (FITC)/propidium iodide (PI) double stained cells showed that the mock treatment and the bornyl cis-4-hydroxycinnamate treatment at 3, 6, and $12 \mu \mathrm{M}$ led A2058/A375 cells to display early apoptosis, at levels of $0.02 \% / 0.22 \%, 2.9 \% / 12.3 \%, 3.37 \% / 13.46 \%$, and $7.82 \% / 24.84 \%$, respectively (Figure 3). These results demonstrated that bornyl cis-4-hydroxycinnamate efficiently induced early apoptosis in A2058 and A375 melanoma cells. 


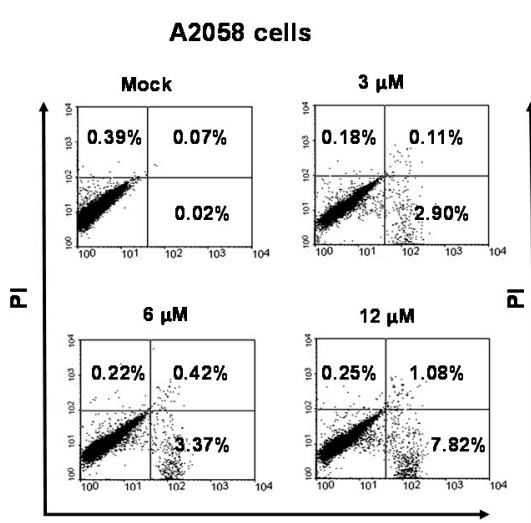

Annexin V

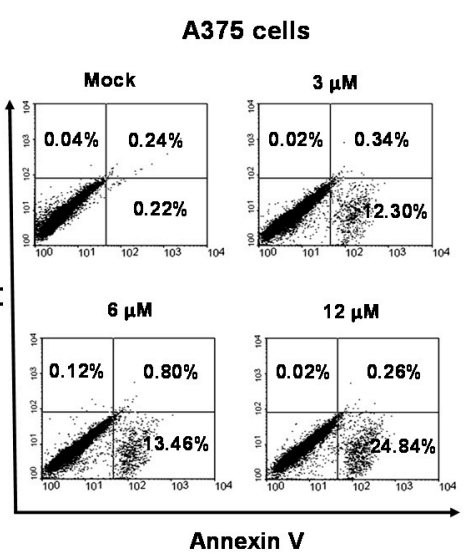

Figure 3. Bornyl cis-4-hydroxycinnamate-induced apoptosis in A2058 and A375 melanoma cells. Detection of apoptotic A2058 and A375 cells after bornyl cis-4-hydroxycinnamate treatment by flow cytometry based-annexin V-fluorescein isothiocyanate (FITC)/propidium iodide (PI) analysis.

\subsection{Proteomic Analysis of Bornyl cis-4-Hydroxycinnamate-Treated A375 Cells}

Following $12 \mu \mathrm{M}$ bornyl cis-4-hydroxycinnamate treatment for $24 \mathrm{~h}$, proteomic analysis was used to identify critical proteins involved in its cellular effect in A375 cells. Two-dimensional electrophoresis (2-DE) analysis with PDQuest image analysis software (Bio-Rad, Hercules, CA, USA) indicated that several proteins exhibited an intensity difference greater than 1.5 -fold in the 2-DE maps. After gel digestion, liquid chromatograph (LC)-MS/MS analysis and MASCOT search engine v2.3 (Matrix Science, London, UK) protein identification demonstrated that a total of 35 differential protein spots were significantly altered between the control and the bornyl cis-4-hydroxycinnamate-treated A375 cells. In Table 1, the 35 identified proteins, with their detailed information, including calculated Mw (molecular weight)/pI (isoelectric point), MS/MS matched sequence coverage, MASCOT scores, fold changes (up-/downregulation), cellular location, and protein function, are presented. Among the 35 differentially expressed proteins, 18 were upregulated after bornyl cis-4-hydroxycinnamate treatment, i.e., nucleophosmin, hypoxia-upregulated protein 1 , sodium/potassium-transporting ATPase subunit $\alpha-1$, Hsp90, ATP synthase subunit $\beta$, vimentin, transitional endoplasmic reticulum ATPase (TER ATPase), proliferating cell nuclear antigen, tubulin $\beta-4$, prohibitin, glycogen phosphorylase, stress 70 , fructose-bisphosphate aldolase A, glucose-regulated protein 78 (GRP78), glyceraldehyde-3-phosphate dehydrogenase (GAPDH), RNA-binding protein 8A, and Ran-specific GTPase-activating protein. On the other hand, 17 proteins were downregulated after bornyl cis-4-hydroxycinnamate treatment, i.e., voltage-dependent anion-selective channel protein, clathrin heavy chain 1, C-1-tetrahydrofolate synthase, serine hydroxymethyltransferase, poly $(\mathrm{rC})$-binding protein 2, protein $\mathrm{DJ}-1$, prelamin-A/C, bifunctional UDP- $\mathrm{N}$-acetylglucosamine 2-epimerase $/ N$-acetylmannosamine kinase, $\alpha$-enolase, elongation factor thermo unstable (EF-Tu), dihydrolipoyl dehydrogenase, heat-shock protein $105 \mathrm{kDa}$, tryptophan-tRNA ligase, triosephosphate isomerase, elongation factor 2 and 3-hydroxyacyl-CoA (coenzyme A) dehydrogenase type-2. 
Table 1. The regulation (fold changes) of the differentially expressed proteins refers to a $24 \mathrm{~h}$ treatment with bornyl cis-4-hydroxycinnamate.

\begin{tabular}{|c|c|c|c|c|c|c|c|c|c|}
\hline Spot No. & Protein Name & Accession. No. & $\mathrm{Mw} / \mathrm{pI}$ & $\begin{array}{l}\text { Peptide } \\
\text { Matched }\end{array}$ & $\begin{array}{c}\text { Sequence } \\
\text { Covered (\%) }\end{array}$ & $\begin{array}{l}\text { MASCOT } \\
\text { Score }\end{array}$ & $\begin{array}{c}\text { Regulation } \\
\text { (Fold-Change) }\end{array}$ & $\begin{array}{l}\text { Cellular } \\
\text { Component }\end{array}$ & Protein Function \\
\hline 1 & Nucleophosmin & P06748 & $32.72 / 4.64$ & 40 & 30 & 1737 & +1.53 & Nucleus & $\begin{array}{l}\text { Regulation of ARF-p53 tumor } \\
\text { suppressor pathway }\end{array}$ \\
\hline 2 & $\begin{array}{l}\text { Sodium/potassium-transporting } \\
\text { ATPase subunit } \alpha-1\end{array}$ & P05023 & $114.15 / 5.33$ & 47 & 28 & 2125 & +2.76 & Mitochondrion & $\begin{array}{l}\text { Sodium/potassium-exchanging } \\
\text { ATPase activity }\end{array}$ \\
\hline 3 & Hsp90 & P08238 & $83.56 / 4.97$ & 113 & 49 & 3086 & +2.74 & Cytoplasm & Protein folding \\
\hline 4 & $\begin{array}{l}\text { Hypoxia upregulated protein } 1 \\
\text { (heat shock protein } 70 \text { family) }\end{array}$ & Q9Y4L1 & $111.49 / 5.16$ & 6 & 6 & 52 & +2.21 & $\begin{array}{l}\text { Endoplasmic } \\
\text { reticulum }\end{array}$ & Stress response \\
\hline 5 & ATP synthase subunit $\beta$ & P06576 & $56.52 / 5.26$ & 51 & 57 & 1865 & +2.89 & Mitochondrion & $\begin{array}{l}\text { Mitochondrial membrane } \\
\text { ATP synthase }\end{array}$ \\
\hline 6 & Vimentin & P08670 & $53.67 / 5.06$ & 5 & 9 & 58 & +2.72 & Cytoplasm & Cytoskeletal protein \\
\hline 7 & $\begin{array}{l}\text { Transitional endoplasmic } \\
\text { reticulum ATPase }\end{array}$ & P55072 & $89.96 / 5.14$ & 29 & 20 & 432 & +3.12 & $\begin{array}{l}\text { Endoplasmic } \\
\text { reticulum }\end{array}$ & $\begin{array}{l}\text { Involved in the formation of the } \\
\text { transitional endoplasmic } \\
\text { reticulum (tER) }\end{array}$ \\
\hline 8 & $\begin{array}{l}\text { Voltage-dependent anion-selective } \\
\text { channel protein }\end{array}$ & P21796 & $30.87 / 8.62$ & 42 & 68 & 1261 & -1.55 & Cytoplasm & $\begin{array}{l}\text { Involved in cell volume regulation } \\
\text { and apoptosis }\end{array}$ \\
\hline 9 & Proliferating cell nuclear antigen & P12004 & $29.09 / 4.57$ & 61 & 73 & 1246 & +1.36 & Nucleus & DNA repair and damage \\
\hline 10 & Tubulin $\beta-4 \mathrm{~B}$ & P68371 & $50.26 / 4.79$ & 27 & 40 & 601 & +3.4 & Cytoplasm & $\begin{array}{l}\text { Structural constituent } \\
\text { of cytoskeleton }\end{array}$ \\
\hline 11 & Prohibitin & P35232 & $29.84 / 5.57$ & 73 & 78 & 2345 & +1.51 & Mitochondrion & Inhibits DNA synthesis \\
\hline 12 & Clathrin heavy chain 1 & Q00610 & $193.29 / 5.48$ & 41 & 29 & 1104 & -1.51 & Cytoplasm & Intracellular trafficking \\
\hline 13 & C-1-tetrahydrofolate synthase & P11586 & $102.19 / 6.89$ & 6 & 6 & 54 & -1.56 & Cytoplasm & Hydrolase \\
\hline 14 & Glycogen phosphorylase & P11216 & $97.33 / 6.40$ & 43 & 44 & 1331 & +1.59 & Mitochondrion & Glycosyltransferase \\
\hline 15 & Serine hydroxymethyltransferase & P34897 & $56.42 / 8.76$ & 22 & 18 & 198 & -2.11 & Mitochondrion & Associates with mitochondrial DNA \\
\hline 16 & Poly $(\mathrm{rC})$-binding protein 2 & P40555 & $37.99 / 6.66$ & 30 & 28 & 491 & -1.52 & Cytoplasm & Chaperone \\
\hline 17 & Protein DJ-1 & Q99497 & $20.05 / 6.33$ & 56 & 68 & 2434 & -3.21 & $\begin{array}{l}\text { Endoplasmic } \\
\text { Reticulum }\end{array}$ & $\begin{array}{l}\text { Protects cells against oxidative stress } \\
\text { and cell death }\end{array}$ \\
\hline 18 & $\begin{array}{c}\text { Prelamin-A/C } \\
\text { Bifunctional }\end{array}$ & P02545 & $74.38 / 6.57$ & 67 & 48 & 2452 & -3.13 & Nucleus & Structural molecule activity \\
\hline 19 & $\begin{array}{c}\text { UDP- } N \text {-acetylglucosamine } \\
\text { 2-epimerase/ } N \text {-acetylmannosamine } \\
\text { kinase }\end{array}$ & Q9Y223 & $80.21 / 6.32$ & 3 & 2 & 102 & -1.52 & Cytoplasm & $\begin{array}{l}\text { Regulates and initiates biosynthesis } \\
\text { of } N \text {-acetylneuraminic acid }\end{array}$ \\
\hline 20 & Fructose-bisphosphate aldolase A & P04075 & $39.85 / 8.30$ & 6 & 10 & 121 & +3.25 & Cytoplasm & $\begin{array}{l}\text { Plays a key role in glycolysis } \\
\text { and gluconeogenesis }\end{array}$ \\
\hline 21 & $\alpha$-enolase & P06733 & $47.48 / 7.01$ & 355 & 75 & 8369 & -1.81 & Cytoplasm & $\begin{array}{l}\text { Multifunctional enzyme } \\
\text { (Transcription regulation) }\end{array}$ \\
\hline 22 & Elongation factor $\mathrm{Tu}$, & P49411 & $49.85 / 7.26$ & 201 & 69 & 5544 & -2.36 & Mitochondrion & Elongation factor \\
\hline 23 & $\alpha$-enolase & P06733 & $47.48 / 7.01$ & 143 & 76 & 3720 & -2.94 & Cytoplasm & Lyase \\
\hline 24 & Stress-70 protein & P38646 & $73.92 / 5.87$ & 432 & 72 & 11,267 & +3.15 & Mitochondrion & Chaperone \\
\hline 25 & $\begin{array}{l}\text { Dihydrolipoyl dehydrogenase, } \\
\text { mitochondrial }\end{array}$ & P09622 & $54.72 / 7.95$ & 28 & 27 & 630 & -2.73 & Mitochondrion & Oxidoreductase \\
\hline
\end{tabular}


Table 1. Cont.

\begin{tabular}{|c|c|c|c|c|c|c|c|c|c|}
\hline Spot No. & Protein Name & Accession. No. & $\mathrm{Mw} / \mathrm{pI}$ & $\begin{array}{l}\text { Peptide } \\
\text { Matched }\end{array}$ & $\begin{array}{c}\text { Sequence } \\
\text { Covered (\%) }\end{array}$ & $\begin{array}{l}\text { MASCOT } \\
\text { Score }\end{array}$ & $\begin{array}{c}\text { Regulation } \\
\text { (Fold-Change) }\end{array}$ & $\begin{array}{c}\text { Cellular } \\
\text { Component }\end{array}$ & Protein Function \\
\hline 26 & Heat-shock protein 105 kDa & Q92598 & $97.73 / 5.28$ & 120 & 60 & 2474 & -1.52 & Cytoplasm & Response to unfolded protein \\
\hline 27 & Tryptophan-tRNA ligase & P23381 & $53.48 / 5.83$ & 57 & 52 & 1802 & -1.53 & Cytoplasm & ATP binding \\
\hline 28 & GRP78 & P11021 & $72.40 / 2.07$ & 49 & 53 & 1322 & +3.23 & $\begin{array}{l}\text { Endoplasmic } \\
\text { reticulum }\end{array}$ & Stress response \\
\hline 29 & $\begin{array}{l}\text { Glyceraldehyde-3-phosphate } \\
\text { dehydrogenase (GAPDH) }\end{array}$ & P04406 & $36.20 / 8.57$ & 88 & 84 & 1998 & +1.54 & Cytoplasm & Assembly of the cytoskeleton \\
\hline 30 & Triosephosphate isomerase & P60174 & $31.06 / 5.65$ & 54 & 70 & 1494 & -2.78 & Cytoplasm & Triose-phosphate isomerase activity \\
\hline 31 & ATP synthase subunit $\beta$ & P06576 & $56.52 / 5.26$ & 23 & 37 & 524 & +2.29 & Mitochondrion & $\begin{array}{l}\text { Mitochondrial membrane } \\
\text { ATP synthase }\end{array}$ \\
\hline 32 & RNA-binding protein $8 \mathrm{~A}$ & Q9Y5S9 & $19.93 / 5.50$ & 15 & 33 & 348 & +1.57 & Nucleus & mRNA binding \\
\hline 33 & $\begin{array}{l}\text { Ran-specific } \\
\text { GTPase-activating protein }\end{array}$ & P43487 & $23.47 / 5.19$ & 24 & 54 & 484 & +1.52 & Cytoplasm & GTPase activation \\
\hline 34 & Elongation factor 2 & P13639 & $96.26 / 6.41$ & 175 & 58 & 2493 & -1.51 & Cytoplasm & GTPase activity \\
\hline 35 & $\begin{array}{l}\text { 3-hydroxyacyl-CoA } \\
\text { dehydrogenase type-2 }\end{array}$ & Q99714 & $27.13 / 7.66$ & 59 & 86 & 1770 & -1.55 & Mitochondrion & Mitochondrial tRNA maturation \\
\hline
\end{tabular}


Differential proteins, such as stress 70, prohibitin, protein DJ-1, GRP78, ATP synthase, and TER ATPase were found to be associated with the induction of apoptosis and acted against cell proliferation. Western blotting was used to validate the changed profiles of these proteins. Altogether, proteomic analysis of 2-DE data and western blotting were in agreement in terms of the trends of changes of these identified proteins (Figure 4B).

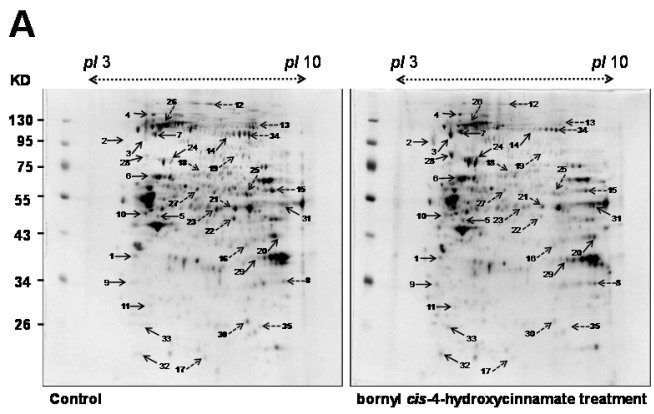

B

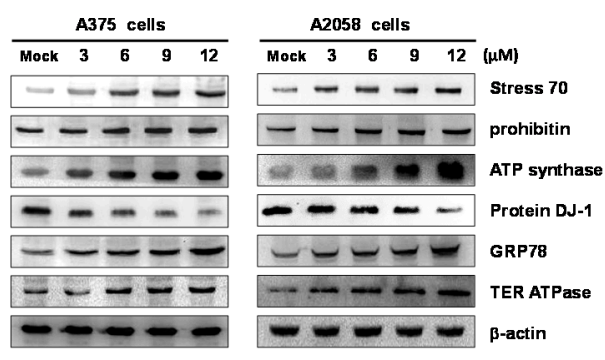

Figure 4. (A) The protein spots marked on 2-DE maps considered differentially expressed were identified by LC-MS/MS. The analysis was repeated three times. Isoelectric focusing (IEF) studies using 11-cm IPG strips (pI 3-10, Immobiline DryStrip). (B) Western blotting assay to validate the identified selected proteins from 2-DE, including stress 70, prohibitin, protein DJ-1, glucose-regulated protein 78 (GRP78), ATP synthase, and TER ATPase. Mock: control, dimethyl sulfoxide (DMSO)-treated cells. $\beta$-actin was used as the internal control. The solid arrows indicate upregulated proteins; the dashed arrows indicate downregulated proteins.

\subsection{Bornyl cis-4-Hydroxycinnamate Activates the Apoptosis Pathway through the Induction of Mitochondrial Depolarization}

As per the aforementioned results showing that bornyl cis-4-hydroxycinnamate induced apoptosis, we also noted that several mitochondrial-related proteins were identified in the bornyl cis-4-hydroxycinnamate-treated cells from 2-DE analysis, including prohibitin, stress 70, and ATP synthase subunit $\beta$. These proteins are known to be involved in energy production. We then employed the tetraethylbenzimidazolylcarbocyanine iodide (JC)-1 dye to measure the loss of mitochondrial membrane potential $(\Delta \psi \mathrm{m})$ in A2058 and A375 cells after bornyl cis-4-hydroxycinnamate treatment. Fluorescence microscopy showed that bornyl cis-4-hydroxycinnamate-treated cells had a lower intensity of red fluorescence and a higher intensity of green florescence due to $\Delta \psi \mathrm{m}$ loss (Figure 5A). The mitochondrial-mediated apoptosis pathway plays an important role in apoptosis. We further analyzed molecules involved in the mitochondrial-mediated apoptosis pathway by examining the expression of related protein markers, including Bcl-2, Bcl-xl, Mcl-1, Bad, p-Bad, Bax, and cytosolic cytochrome $C$. As shown in Figure 5B, bornyl cis-4-hydroxycinnamate significantly increased the expression levels of Bad, Bax, and cytosolic cytochrome $C$ in A2058 and A375 cells. In contrast, the levels of other marker proteins, such as Bcl-2, Bcl-xl, Mcl-1, and p-Bad, were decreased after bornyl cis-4-hydroxycinnamate treatment. 
A
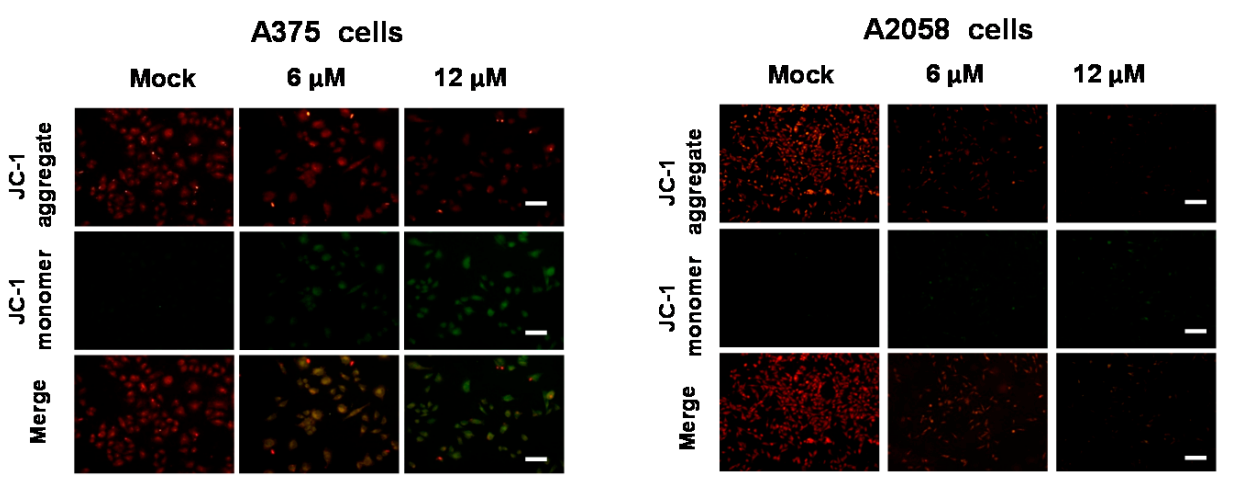

B
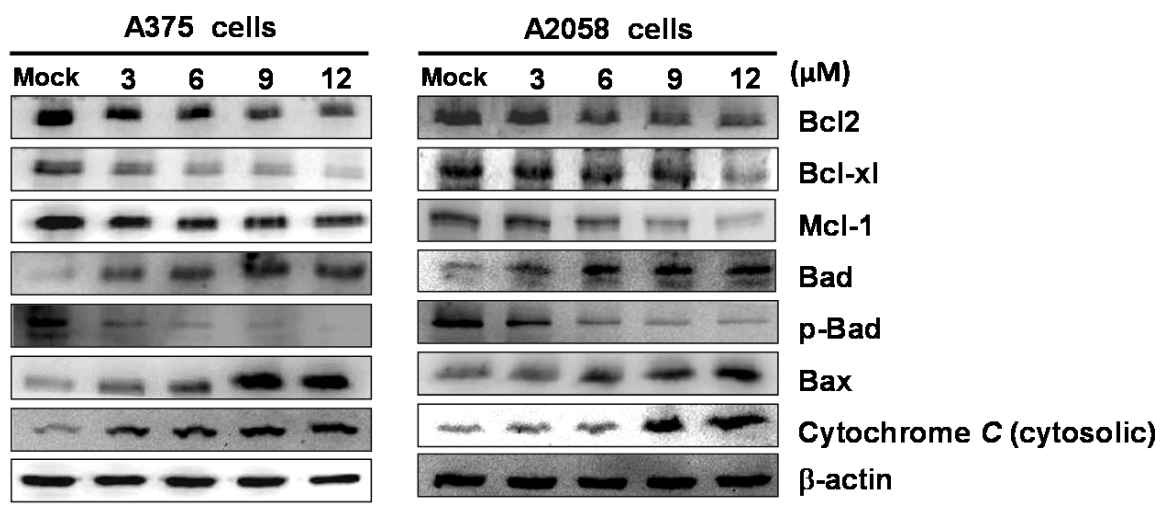

Figure 5. Bornyl cis-4-hydroxycinnamate induced apoptosis through mitochondria potential $(\Delta \psi \mathrm{m})$ change and the mitochondrial-mediated pathway in A2058 and A375 melanoma cells. (A) A2058 and A375 melanoma cells were treated with or without bornyl cis-4-hydroxycinnamate; $\Delta \psi \mathrm{m}$ in melanoma cells was detected by JC-1 staining and analyzed using fluorescence microscopy. Scale bar: $50 \mu \mathrm{m}$. (B) Changes in Bcl-2, Bcl-xl, Mcl-1, Bad, p-Bad, Bax, and cytosolic cytochrome $C$ expression in two melanoma cells treated with different concentrations of bornyl cis-4-hydroxycinnamate visualized by western blotting analysis. $\beta$-actin was used as the internal control.

\subsection{Bornyl cis-4-Hydroxycinnamate Activates the Caspase-Dependent Pathway Leading to Cell Apoptosis}

To confirm the role of caspase in bornyl cis-4-hydroxycinnamate-induced apoptosis, the levels of caspase-3, caspase- 8 , caspase-9, and poly(ADP-ribose) polymerase (PARP)-1 were used to evaluate the status of caspase and its downstream effectors after bornyl cis-4-hydroxycinnamate treatment. As shown in Figure 6A, the expression of cleaved caspase-3 (17 kDa large subunit), cleaved caspase-9 (37 kDa large subunit), and cleaved PARP ( $89 \mathrm{kDa}$ carboxyterminal catalytic domain) was increased in bornyl cis-4-hydroxycinnamate-treated A2058 and A375 melanoma cells, while the levels of pro-caspase-3 and pro-caspase-9 were decreased after bornyl cis-4-hydroxycinnamate treatment; the expression levels of caspase- 8 were unchanged. These observations suggested that bornyl cis-4-hydroxycinnamate treatment activated the caspase-dependent pathway. To confirm whether the activation of the caspase cascade is crucial in bornyl cis-4-hydroxycinnamate-induced cell apoptosis, we used inhibitors against caspase-3 (Z-DEVD-FMK) and caspase-9 (Z-VAD-FMK). As shown in Figure $6 \mathrm{~B}$, cell death was suppressed in cells treated with either of these two inhibitors, suggesting that bornyl cis-4-hydroxycinnamate-induced apoptosis is mediated by caspase- 3 and caspase- 9 in melanoma cells. 
A
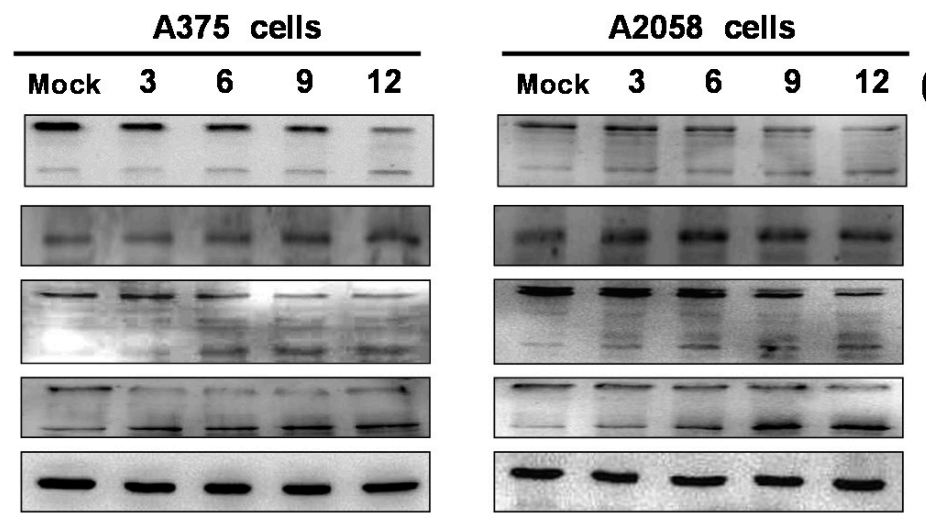

( $\mu \mathrm{M})$

pro-caspase-3

cleaved-caspase-3

Caspase-8

pro-caspase-9

cleaved-caspase-3

PARP-1

B

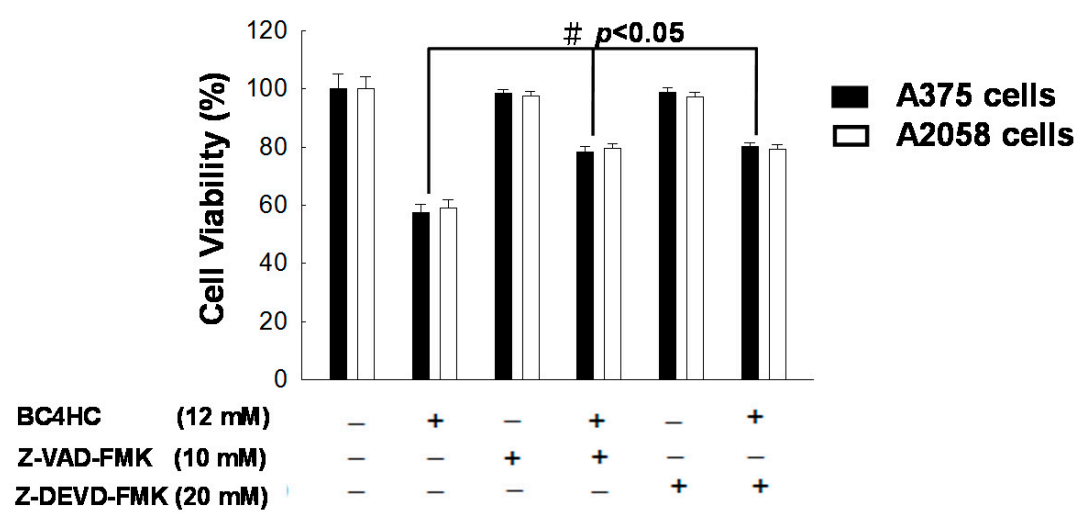

Figure 6. Bornyl cis-4-hydroxycinnamate induced apoptosis through caspase-dependent pathways. (A) The western blots show changes in apoptosis-associated protein expression levels in A2058 and A375 melanoma cells after treatment with bornyl cis-4-hydroxycinnamate. (B) Caspase-3 and caspase- 9 inhibitors affected the viability of A2058 and A375 melanoma cells treated with bornyl cis-4-hydroxycinnamate. The cells were seeded onto a 24-well plate and pretreated with or without Z-DEVD-FMK (caspase-3 inhibitor) and Z-VAD-FMK (caspase-9 inhibitor), then treated with $12 \mu \mathrm{M}$ bornyl cis-4-hydroxycinnamate. An MTT assay was performed for the evaluation of cell viability. Data are presented as mean $\pm \mathrm{SD}$. of at least three experiments independently. The results were analyzed with the statistical approach Student's $t$-test ( ${ }^{\#} p<0.05$, compared with bornyl cis-4-hydroxycinnamate treatment groups). (BC4HC: bornyl cis-4-hydroxycinnamate).

\subsection{Bornyl cis-4-Hydroxycinnamate Treatment Induces the Endoplasmic Reticulum (ER) Stress Pathway}

Next, we investigated whether the ER stress pathway was involved in bornyl cis-4-hydroxycinnamate-induced apoptosis in melanoma cells. Using western blot analysis, the expression levels of ER-related proteins GRP78 and TER ATPase were found to increase in the melanoma cells after bornyl cis-4-hydroxycinnamate treatment in a dose-dependent manner (Figure 4B). We then further verified the expression of three ER-resident transmembrane sensor proteins, i.e., endoribonuclease inositol-requiring enzyme $1 \alpha$ (IRE1 $\alpha)$, protein kinase RNA-like endoplasmic reticulum kinase (PERK), and activating transcription factor 6 (ATF6), as well as of caspase- 12 by western blot. The results showed that the expression of IRE1 $\alpha$ and caspase- 12 was unchanged after bornyl cis-4-hydroxycinnamate treatment. Under ER stress, endogenous ATF6 (p90 ATF6) is cleaved into a $50 \mathrm{KDa}$ fragment transcription factor (p50 ATF6) and enters the nucleus to activate the GRP78 genes [16]. Our results showed that p-PERK and p-eIF2 $\alpha$ expression increased after bornyl cis-4-hydroxycinnamate treatment. The level of transcription factor ATF4, a downstream target of PERK in the PERK-eIF2 $\alpha$ pathway, was also increased after treatment in A2058 and A375 melanoma cells. Additionally, the expression and nuclear translocation of ER stress-induced 
CCAAT/enhancer-binding protein (C/EBP)-homologous protein $(\mathrm{CHOP})$ was also increased by bornyl cis-4-hydroxycinnamate treatment (Figure 7A).

Bornyl cis-4-hydroxycinnamate increased the ER stress-related protein expression levels similar to the two ER stress inducer agents tunicamycin (Tm) and thapsigargin (Tg), used to monitor the ER stress response. These results imply that bornyl cis-4-hydroxycinnamate-triggered cell apoptosis is mediated by the ER stress pathway in A2058 and A375 melanoma cells (Figure 7B).

A

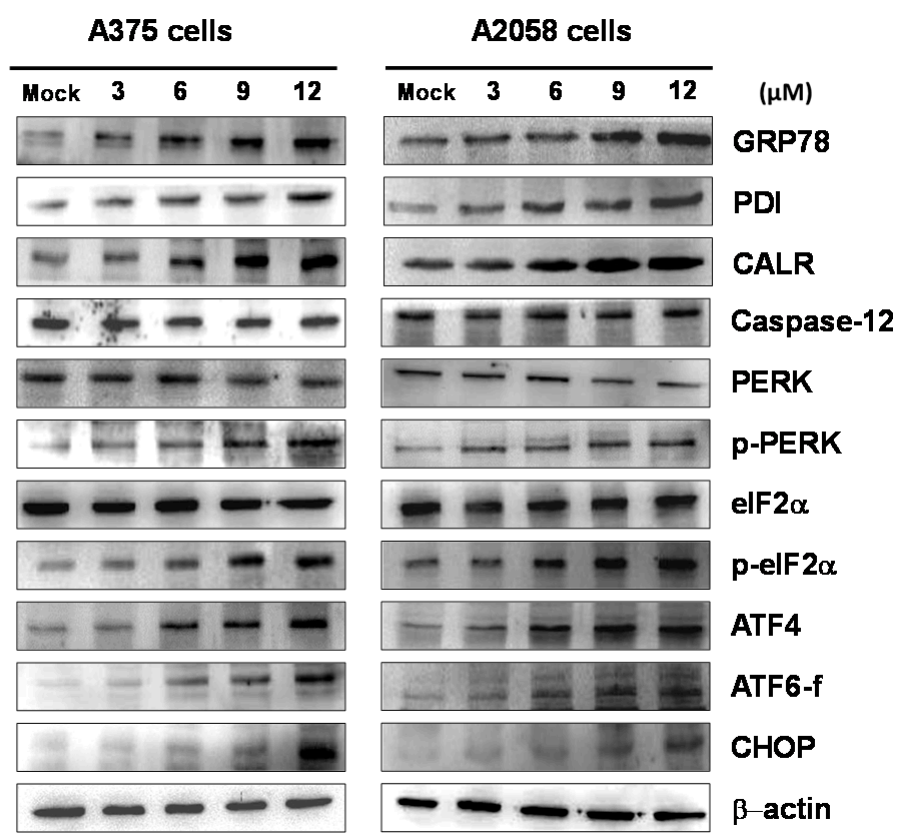

B

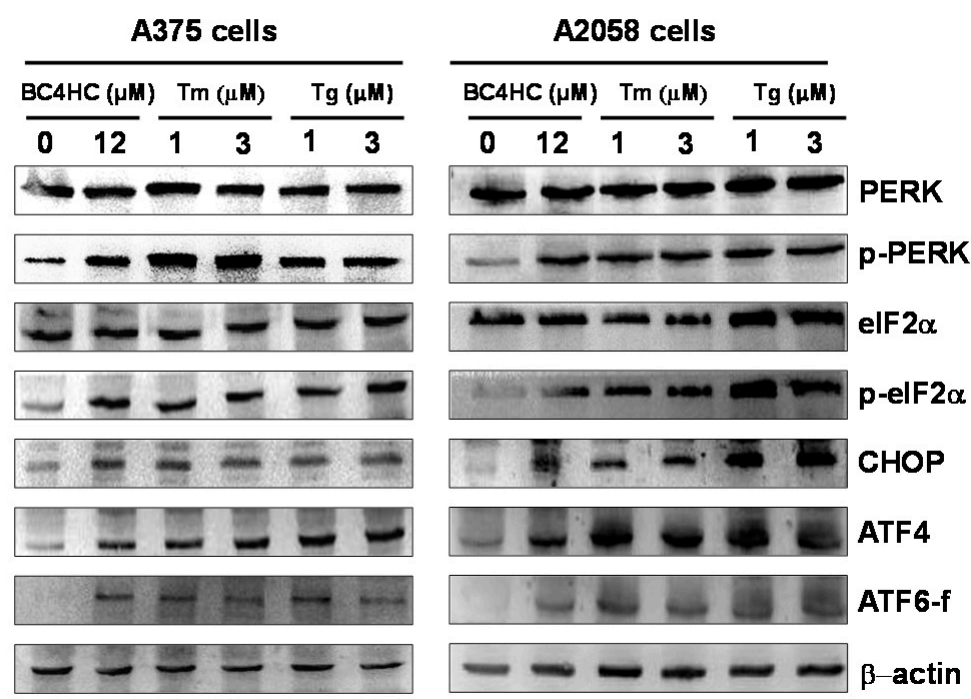

Figure 7. Expressions of endoplasmic reticulum (ER) stress-induced proteins in A375 and A2058 melanoma cells after bornyl cis-4-hydroxycinnamate treatment. (A) Expressions levels of ER stress response-related proteins in A2058 and A375 melanoma cells after bornyl cis-4-hydroxycinnamate treatment. (BC4HC: bornyl cis-4-hydroxycinnamate) (B) The increases in the expression levels of bornyl cis-4-hydroxycinnamate-induced ER stress-related protein were similar to those produced by the two ER stress-inducers agents, tunicamycin (Tm) and thapsigargin (Tg). 
To further demonstrate that bornyl cis-4-hydroxycinnamate-induced apoptosis occurs through ER stress-related pathways as described above, salubrinal (an inhibitor) was tested to examine PERK-activated cell apoptosis upon bornyl cis-4-hydroxycinnamate treatment. An increase in cell viability from $64 \%$ to $78 \%$ was observed in bornyl cis-4-hydroxycinnamate-treated A2058 and A375 cells following treatment with salubrinal at a concentration of $10 \mu \mathrm{M}$ (Figure 8).
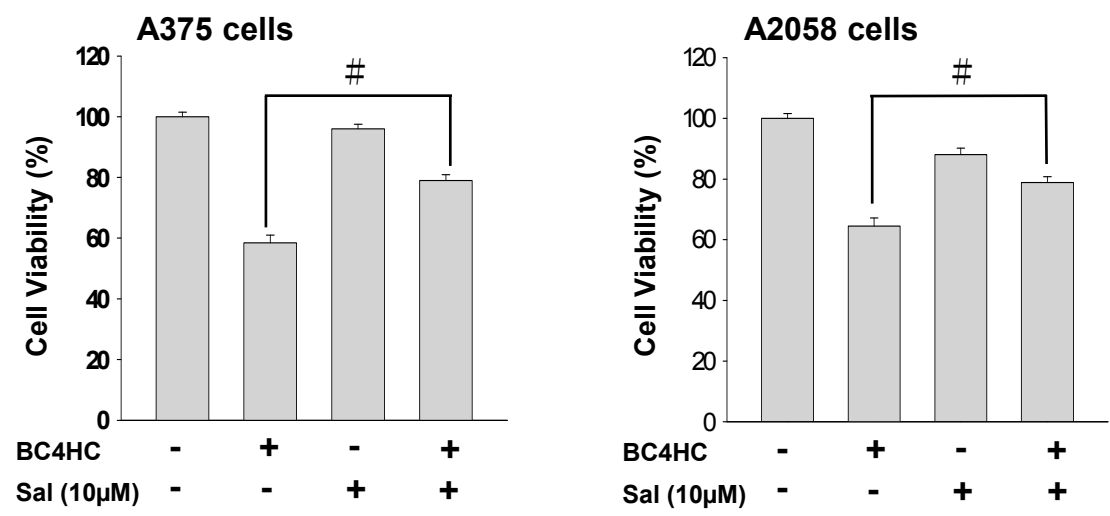

Figure 8. Cell survival after bornyl cis-4-hydroxycinnamate treatment was verified using the inhibitor salubrinal (Sal). The cells incubated with bornyl cis-4-hydroxycinnamate and salubrinal displayed increased survival compared to those treated with bornyl cis-4-hydroxycinnamate alone. Salubrinal treatment confirmed bornyl cis-4-hydroxycinnamate-induced apoptosis and inhibition of cell proliferation in melanoma cells. Data are presented as mean \pm SD. of at least three experiments independently. The results were analyzed with the statistical approach Student's $t$-test ${ }^{\#} p<0.05$, compared with BC4HC treatment groups).

\section{Discussion}

In the current study, we investigated the cytotoxic effect of bornyl cis-4-hydroxycinnamate, isolated from P. betel stems, and studied the signaling pathways involved in the apoptosis induced by bornyl cis-4-hydroxycinnamate in melanoma cells. Our results demonstrate that bornyl cis-4-hydroxycinnamate inhibited cell proliferation (Figure 2) and increased early apoptosis rates (Figure 3) in A2058 and A375 melanoma cells, in a concentration-dependent manner. These findings support the conclusion that bornyl cis-4-hydroxycinnamate possesses activity against cell proliferation and may induce apoptosis in melanoma cells.

The molecular mechanism involved in bornyl cis-4-hydroxycinnamate-induced apoptosis in A375 melanoma cells was elucidated from proteomic data, which showed significant changes in the expression of several crucial proteins, including sodium/potassium-transporting ATPase subunit $\alpha-1$, ATP synthase subunit $\beta$, prohibitin, stress 70 protein, dihydrolipoyl dehydrogenase, and 3-hydroxyacyl-CoA dehydrogenase type-2, which are associated with mitochondrial function or apoptosis in melanoma cells. Prohibitin is located in the mitochondria and is known to regulate apoptosis, cellular signaling, cell migration, and cell proliferation and to stabilize mitochondria proteins [17-20]. The translocation of prohibitin to mitochondria together with p53 has been shown to be highly correlated with the suppression of cancer growth [21,22]. Therefore, the antiproliferative effects of bornyl cis-4-hydroxycinnamate are likely mediated by the mitochondria in A2058 and A375 cells and associated with the enhancement of prohibitin.

The apoptosis induced by bornyl cis-4-hydroxycinnamate is also a good indicator of the potential success of this molecule in the treatment of melanoma, as the development of anticancer drugs has often been based on the apoptosis effect as a potential mechanism of chemotherapy [23]. The mechanisms of apoptosis can be subdivided into two major pathways, i.e., the extrinsic and the intrinsic pathways. The former is also called the death receptor pathway, and the latter is also known as the mitochondrial pathway [24]. A study has suggested that the two pathways are related and influence each other [25], 
and molecules in the intrinsic pathway are located in either the ER or the mitochondria [26]. In addition, increased expression levels of the pro-apoptotic Bax and Bak proteins and decreased expression levels of the anti-apoptotic Bcl-2, Bcl-xl, and Mcl-1 proteins are known to play important roles in the intrinsic pathway and are associated with changes in the mitochondrial membrane potential and with the release of mitochondrial apoptotic factors [27]. The collapse of $\Delta \psi \mathrm{m}$ subsequently leads to cytochrome $C$ release into the cytosol, resulting in caspase- 9 activation, and further activates the downstream effector caspase-3. This process then causes poly(ADP-ribose) polymerase cleavage [28]. Existing information and our findings showing decreased $\Delta \psi \mathrm{m}$ and cytochrome $C$ release from the mitochondria (Figure 5B) suggest that bornyl cis-4-hydroxycinnamate-induced apoptosis in A2058 and A375 cells occurs via the mitochondrial pathway. Additionally, the suppression of the anti-apoptotic Bcl-2, Bcl-xl, and Mcl-1 proteins and the augmented expression of the pro-apoptotic Bad and Bax proteins (Figure 5B), as well as the activation of caspase-3, caspase-9, and PARP (Figure 6), indicate that the caspase activation cascades are crucial in bornyl cis-4-hydroxycinnamate-induced apoptosis in A2058 and A375 cells.

The ER plays many important roles in regulating essential cellular functions, including proper protein folding, protein synthesis, and calcium homeostasis [29]. When too many unfolded proteins accumulate in the ER, the homeostasis of the ER is destroyed, causing stress and leading to cells activating a self-rescue program or triggering apoptosis. In the presence of stress, the ER may react in various ways, including the induction of ER-associated degradation (ERAD), of the unfolded protein response (UPR), and of apoptosis [30,31]. Continued and severe ER stress increases the UPR, which will trigger apoptosis [32]. The UPR process is regulated by three ER signaling sensors, named protein kinase RNA-like endoplasmic reticulum kinase (PERK), inositol requiring enzyme $1-\alpha$ (IRE1- $\alpha$ ), and activating transcription factor 6 (ATF6). When unfolded proteins accumulate in the ER, chaperones, such as GRP78/GRP94, will release the transmembrane proteins IRE1- $\alpha$, PERK, and ATF6, resulting in ER dysfunction. The PERK pathway either leads to cell survival controlled by autophagy [33] or to apoptosis by increasing ATF4/CHOP [34]. In the presence of ER stress, the cells activate a self-rescue program to trigger the UPR, which prevents cell death. Persistent ER stress initiates caspase-dependent apoptosis, leading to cell death [35]. When cells are under oxidative stress, unfolded or misfolded proteins accumulate in the ER, causing ER stress, and this imposed ER stress subsequently causes the UPR to alleviate the stress and restore ER homeostasis. The process upregulates chaperone GRP78 and disulfide isomerase protein, which promote protein folding and alleviate protein aggregation, and modulates calreticulin activity for the storing of calcium in the ER [36,37]. Our immunostaining results demonstrated that the levels of GRP78 and calreticulin were increased in the presence of a high concentration of bornyl cis-4-hydroxycinnamate, indicating that these proteins were activated to restore normal protein folding and reduce ER stress. If the UPR is insufficient to relieve cells from ER stress, the PERK, IRE1- $\alpha$, and ATF6 pathways may activate downstream proteins to induce apoptosis in order to destroy the ER stress-damaged cells [38]. It was observed that PERK activates eIF2 $\alpha$, ATF4, and CHOP, causing apoptosis. The immunostaining results of this study also showed that the levels of p-PERK, p-eIF2 $\alpha$, and downstream ATF4 were increased, as was the expression of ATF6. These responses led to the activation of CHOP and increased its expression to induce apoptosis. The level of caspase-12 expression did not change, suggesting that the apoptotic mechanism in our study was mediated by the PERK-eIF2 $\alpha$-ATF4-CHOP signaling pathways in the ER (Figure 7A). In order to verify our hypothesis that bornyl cis-4-hydroxycinnamate-induced apoptosis in melanoma cells is associated with ER stress, we used ER stress agonists, namely, $\operatorname{Tm}$ and $\operatorname{Tg}(1$ and $3 \mu \mathrm{M}$, respectively), to treat the cells. The results showed that the treatment with increasing concentrations of Tm and Tg resulted in trends of the expression of PERK, p-PERK, eIF2 $\alpha$, p-eIF2 $\alpha$, CHOP, ATF4, and ATF6 consistent with those of cells treated with bornyl cis-4-hydroxycinnamate. This finding suggests that bornyl cis-4-hydroxycinnamate-induced apoptosis occurs through a mechanism that involves ER stress (Figure 7B). We also used salubrinal, an eIF2 $\alpha$ inhibitor, to further confirm our hypothesis. An MTT assay showed that the survival rate of cells treated with bornyl cis-4-hydroxycinnamate and salubrinal 
together was significantly higher than that of cells treated with bornyl cis-4-hydroxycinnamate alone (Figure 8). In conclusion, the results indicate that bornyl cis-4-hydroxycinnamate initiated ER stress and subsequently induced apoptosis in melanoma cells.

Overall, our results demonstrate that bornyl cis-4-hydroxycinnamate-induced apoptosis in A2058 and A375 cells is mediated by a dysfunction of the mitochondrial pathway, the activation of caspase cascades, and ER stress.

\section{Materials and Methods}

\subsection{Reagents}

Bornyl cis-4-hydroxycinnamate was isolated from P. betel stem and dissolved in DMSO at a concentration of $100 \mathrm{mM}$ as a stock solution and stored at $-20{ }^{\circ} \mathrm{C}$. The compounds 3-(4,5-dimethylthiazol-2-yl)-2,5-diphenyltetrazolium bromide (MTT), Z-DEVD-FMK (caspase-3 inhibitor), Z-VAD-FMK (caspase-9 inhibitor), tunicamycin (Tm), thapsigargin (Tg), salubrinal, and dimethyl sulfoxide (DMSO), the protease inhibitor cocktail, and rabbit anti-human $\beta$-actin antibodies were purchased from Sigma (St Louis, MO, USA). The chemiluminescent horseradish peroxidase (HRP) substrate was obtained from Pierce (Rockford, IL, USA). Isoelectric focusing (IEF) strips and immobilized $\mathrm{pH}$ gradient (IPG) buffer were obtained from GE Healthcare (Buckinghamshire, UK). Dulbecco's modified Eagle's medium was obtained from Biowest (Nuaillé, France). An annexin V/FITC Apoptosis Detection kit was purchased from Pharmingen (San Diego, CA, USA). The cationic dye JC-1 was purchased from Biotium (Hayward, CA, USA). Rabbit anti-human cytochrome $C$, PARP-1, pro-casapse-3, cleaved caspase-3, pro-caspase-8, pro-caspase-9, cleaved caspase-9, caspase-12, Bax, Bad, p-Bad, Bcl-2, Bcl-xl, Mcl-1, PDI, calreticulin, ATP synthase, stress 70, GRP78, prohibitin, protein DJ-1, transitional endoplasmic reticulum ATPase, IRE1 $\alpha$, PERK, p-PERK, eIF2 $\alpha$, p-eIF2 $\alpha$, ATF4, ATF6-f, and CHOP antibodies were obtained from Cell Signaling Technology (Danvers, MA, USA). Goat anti-rabbit and horseradish peroxidase-conjugated IgG was purchased from Millipore (Bellerica, MA, USA).

\subsection{General Instrumental Operation for the Isolation and Identification of Compounds}

NMR spectra were analyzed in $\mathrm{CDCl}_{3}$ at room temperature using a Varian Mercury plus 400 NMR spectrometer, and the solvent resonance was used as the internal shift reference (tetramethyl silane [TMS] as standard). EI-MS were recorded on a SX-102A mass spectrometer (JEOL USA, Inc., Peabody, MA, USA). Thin-layer chromatography was used on silica gel 60 F254 plates (Merck KGaA, Darmstadt, Germany), and the spots were visualized by spraying with $10 \% \mathrm{H}_{2} \mathrm{SO}_{4}$ solution. Silica gels (230-400 mesh ASTM, Merck KGaA) were used for column chromatography. Semi-preparative HPLC was performed using LiChrosorb Si 60 column, $(7 \mu \mathrm{m}, 250 \times 10 \mathrm{~mm}$; (Merck KGaA) on a LDC Analytical-III system.

\subsection{Source, Extraction, Fractionation, and Purification of P. betle Stem Compounds}

Stems of $P$. betle were collected in Pingtung County, Taiwan. Air-dried stems of P. betle (3 kg) were ground using an electric high-speed grinder until a fine powder that passed through a 10-mesh sieve was obtained, and the powder was extracted with methanol (solid/solvent ratio $=1: 5$ ) at room temperature three times $(7 \mathrm{~d}$ each). The filtrates were pooled and dried under reduced pressure to allow the solvent to evaporate. The dry crude residue was then suspended in water before being successively partitioned with ethyl acetate and $n$-butanol.

The ethyl acetate fraction ( $65 \mathrm{~g}$ ) was separated into 24 fractions on a silica gel column $(5 \times 60 \mathrm{~cm})$, using step-gradient elution with solvent mixtures of n-hexane and ethyl acetate of increasing polarity as eluents. Fraction 10 (4.2 g) was further chromatographed on a silica gel column $(3 \times 45 \mathrm{~cm})$ using step-gradient elution with $\mathrm{CH}_{2} \mathrm{Cl}_{2}$-EtOAc (99:1 to 1:1) to give six fractions (each about $400 \mathrm{~mL}$ ), 
$10 \mathrm{~A}-10 \mathrm{~F}$. Semipreparative HPLC was used to separate Fr. $10 \mathrm{C}$ by using $n$-hexane- $\mathrm{CH}_{2} \mathrm{Cl}_{2}-\mathrm{EtOAC}$ (16:6:1) to elute the sample (32.1 mg; Figure 1).

\subsection{Cell Lines and Cell Culture Conditions}

A2058 and A375 melanoma cells were obtained from the Food Industry Research and Development Institute (Hsinchu, Taiwan). A2058 and A375 melanoma cells were grown in Dulbecco's modified Eagle's medium (DMEM) supplemented with 10\% $(v / v)$ fetal bovine serum, $1 \mathrm{mM}$ sodium pyruvate, $4 \mathrm{mM}$ L-glutamine, $100 \mu \mathrm{g} / \mathrm{mL}$ streptomycin and $100 \mathrm{U} / \mathrm{mL}$ penicillin in a humidified incubator at $37^{\circ} \mathrm{C}$ with $5 \% \mathrm{CO}_{2}$.

\subsection{Cytotoxicity Assessment}

A2058 and A375 cells were seeded in 96-well plates at a density of $1 \times 10^{5} /$ well with $200 \mu \mathrm{L}$ of Dulbecco's modified Eagle medium (DMEM) and 10\% fetal bovine serum in a humidified, $5 \% \mathrm{CO}_{2}$ atmosphere at $37{ }^{\circ} \mathrm{C}$. The cells in each well were treated with bornyl cis-4-hydroxycinnamate (at concentrations of $0,3,6,9,12,15$, and $18 \mu \mathrm{M}$ ) for $24 \mathrm{~h}$. Cells treated with DMSO without bornyl cis-4-hydroxycinnamate were used as a control. After a $24 \mathrm{~h}$ incubation period, $50 \mu \mathrm{L}$ of MTT $(0.5 \mathrm{mg} / \mathrm{mL}$ stock) was added to the cells, followed by incubation for $2 \mathrm{~h}$. The medium was then removed, and DMSO $(200 \mu \mathrm{L})$ was added to dissolve the formazan. The optical density (OD) was determined at $595 \mathrm{~nm}$ on an ELISA reader (Bio-Rad, Hercules, CA, USA) to provide a relative estimate of cell viability. All experiments were performed in at least triplicate to confirm their reproducibility.

\subsection{Flow Cytometric Analysis}

To analyze apoptosis in A2058 and A375 melanoma cells after bornyl cis-4-hydroxycinnamate treatment, the cells were stained with an annexin V-FITC apoptosis staining kit (Pharmingen, San Diego, CA, USA) and analyzed as described in previous reports [39,40]. Briefly, $1 \times 10^{6}$ cells were seeded into $5 \mathrm{~cm}$ Petri dishes and treated with different concentrations of bornyl cis-4-hydroxycinnamate $(3,6$, and $12 \mu \mathrm{M})$ for $24 \mathrm{~h}$. Then, the cells were harvested and stained with annexin V-FITC/propidium iodide (PI) in a cell culture incubator for $30 \mathrm{~min}$. Samples were then assessed using a FACScan flow cytometer (Becton-Dickinson, Mansfield, MA, USA), and the data were analyzed using FlowJo software v10.4.2 (TreeStar, Inc., Ashland, OR, USA).

\subsection{Protein Lysate Preparation}

After bornyl cis-4-hydroxycinnamate treatment $(0,3,6,9$ and $12 \mu \mathrm{M})$ for $24 \mathrm{~h}$, A2058 and A375 cells were lysed with a cell extraction buffer (BioSource International, Camarillo, CA, USA). The supernatants were quantified using a Bio-Rad protein assay for sodium dodecyl sulfate polyacrylamide gel electrophoresis (SDS-PAGE). In addition, some of each supernatant was precipitated using a $10 \%$ cold trichloroacetic acid (TCA)/acetone solution containing $20 \mathrm{mM}$ dithiothreitol (DTT) overnight at $-20{ }^{\circ} \mathrm{C}$. The protein pellet was dissolved in a rehydration buffer ( $2 \mathrm{M}$ thiourea, $6 \mathrm{M}$ urea, $20 \mathrm{mM} \mathrm{DTT}, 0.5 \% \mathrm{IPG}$ buffer, 0.5\% 3-[(3-cholamidopropyl)dimethylammonio]-1-propanesulfonate (CHAPS), and 0.002\% bromophenol blue) at $4{ }^{\circ} \mathrm{C}$, and the protein concentrations were determined using a 2-D Quant Kit (GE Healthcare) for 2-DE analysis.

\subsection{Two-Dimensional Gel Electrophoresis and Differential Proteomic Analyses}

For two-dimensional gel electrophoresis (2-DE), protein samples $(200 \mu \mathrm{g})$ from the control cells and the cells treated with $12 \mu \mathrm{M}$ bornyl cis-4-hydroxycinnamate were analyzed using a GE Healthcare Ettan IPGphor 3. For second-dimension electrophoresis, the equilibrated strip was placed onto the top of a 12.5\% SDS-PAGE gel and run on an SE 600 Ruby Vertical electrophoresis system (Hoefer, 
Holliston, MA, USA). Each sample was run in triplicate, and the spots on the 2-DE gels were visualized by silver staining. The gels were scanned and then analyzed using PDQuest image analysis software v8.0.1 (Bio-Rad). Each triplicate sample was normalized prior to statistical analysis. The protein spots with an intensity difference between the control and bornyl cis-4-hydroxycinnamate-treated cells greater than 1.5-fold were identified, and statistically significant differences in 2-DE between 11-epi-sinulariolide acetate-treated HA22T cells and the control [41] were identified. The protein spots of interest were excised from the 2-DE gels, and in-gel digestion was performed with trypsin. The digested samples were analyzed by LC/MS/MS using a QTRAP $5500 \mathrm{Q}$ mass spectrometer (AB Sciex, Framingham, MA, USA). MS scanning ranged from $m / z 100$ to1000. The raw MS data were converted into the text file format WIFF using Analyst 1.5.1 (AB Sciex, Framingham, MA, USA).

\subsection{Assessment of the Mitochondrial Membrane Potential ( $\Delta \psi m)$}

The mitochondrial membrane potential $(\Delta \psi \mathrm{m})$ was determined using cells stained with the cationic dye JC-1. Briefly, A2058 and A375 cells at $1 \times 10^{5}$ cells/well in a 12-well plate were treated with different concentrations of bornyl cis-4-hydroxycinnamate $(0,3,6$, and $12 \mu \mathrm{M})$. The treated cells were collected and washed twice with PBS, incubated with $70 \mu \mathrm{L}$ of JC-1 staining solution, and placed in a cell culture incubator for $30 \mathrm{~min}$. Following washing with a buffer, the cells were then directly observed under a fluorescence microscope [42].

\subsection{Antibody and Western Blot Analysis}

Western blot analysis was performed according to previous reports. The primary antibodies used were: anti-human stress 70, GRP78, ATP synthase, prohibitin, protein DJ-1, Transitional endoplasmic reticulum ATPase, Bax, Bad, p-Bad, Mcl-1, Bcl-2, Bcl-xl, PARP-1, pro-caspase-3, cleaved-caspase-3, caspase-8, pro-caspase-9, cleaved-caspase-9, cytochrome $C$, PDI, calreticulin, IRE1 $\alpha$, caspase-12, PERK, p-PERK, elf $2 \alpha$, p-eIF2 $\alpha$, ATF4, ATF6-f, CHOP, and $\beta$-actin antibodies. Secondary antibodies (horseradish peroxidase-conjugated goat anti-rabbit, 1:5000 in blocking solution) were added, followed by an incubation for $2 \mathrm{~h}$. The signals were visualized using a chemiluminesence detection kit (Pierce Biotechnology, Rockford, IL, USA).

\subsection{Statistical Analysis}

All experiments were repeated at least in triplicate. Data analysis was performed using Student's $t$ test (Sigma-Stat 2.0, San Rafael, CA, USA); $p$ values $<0.05$ were considered significant.

\section{Conclusions}

Our results established that bornyl cis-4-hydroxycinnamate extracted from P. betel stems possesses the ability to induce apoptosis in A2058 and A375 melanoma cells. A differential proteomic analysis identified several important mitochondrial and endoplasmic reticulum proteins and proved that mitochondrial dysfunction and the activation of endoplasmic reticulum stress pathways are key molecular mechanisms in the apoptosis induced by bornyl cis-4-hydroxycinnamate (Figure 9). Our findings provide evidence that bornyl cis-4-hydroxycinnamate has the potential to be developed as new therapeutic agent for melanoma treatment. 


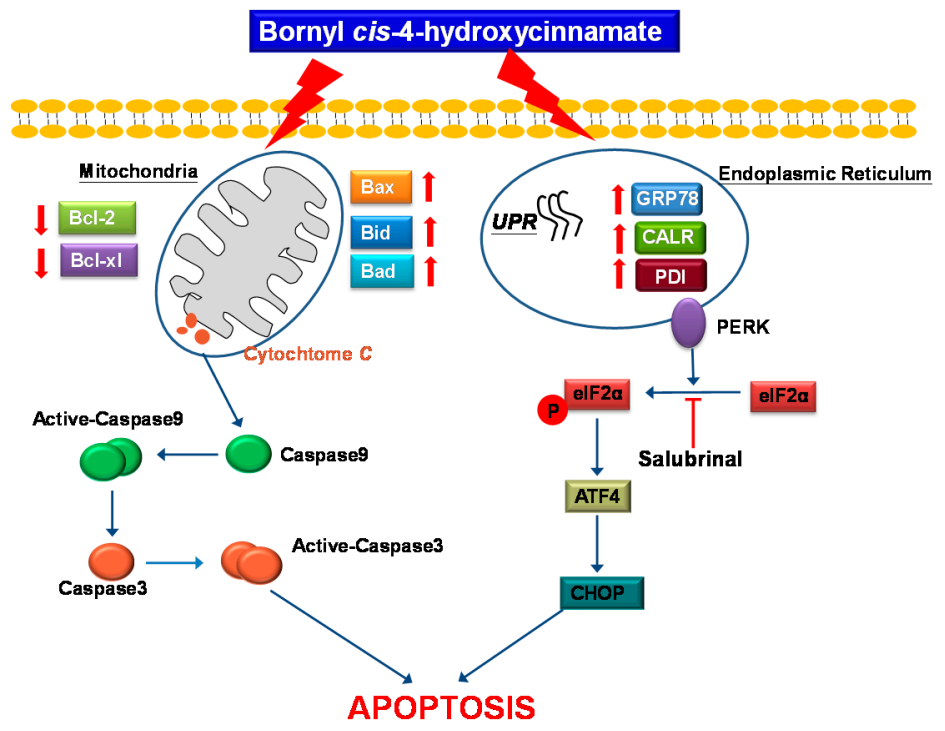

Figure 9. Bornyl cis-4-hydroxycinnamate-induced apoptotic pathway in A2058 and A375 melanoma cells. The anti-ancer effect of bornyl cis-4-hydroxycinnamate is mediated by the induction of mitochondria dysfunction and ER stress signaling pathways.

Author Contributions: M.-L.W. and Y.-J.W. conceived and designed the experiments. C.-I.C. performed the sample collections, extraction, isolation, and structures determination; the pharmacological experiments were carried out by T.-Y.Y. and Y.-J.W.; C.-C.C. contributed reagents and analysis tools; T.-Y.Y., M.-L.W., and Y.-J.W. participated in data interpretation, wrote the manuscript, and revised the paper.

Acknowledgments: This study was supported in part by a grant from the National Science Council Research (MOST 105-2313-B-276-001-MY3) by Y.-J.W.

Conflicts of Interest: The authors declare no conflict of interest.

\section{References}

1. Parkin, D.M.; Bray, F.; Ferlay, J.; Pisani, P. Global cancer statistics, 2002. CA A Cancer J. Clin. 2005, 55, 74-108. [CrossRef]

2. American Cancer Society. Melanoma Skin Cancer. Available online: https://www.cancer.org/cancer/ melanoma-skin-cancer/about.html (accessed on 19 November 2017).

3. Fuglede, N.; Brinck-Claussen, U.; Deltour, I.; Boesen, E.; Dalton, S.; Johansen, C. Incidence of cutaneous malignant melanoma in denmark, 1978-2007. Br. J. Dermatol. 2011, 165, 349-353. [CrossRef] [PubMed]

4. Sasse, A.D.; Sasse, E.C.; Clark, L.; Ulloa, L.; Clark, O. Chemoimmunotherapy versus chemotherapy for metastatic malignant melanoma. Cochrane Database Syst. Rev. 2007, 24, CD005413. [CrossRef] [PubMed]

5. Tawbi, H.A.; Buch, S.C. Chemotherapy resistance abrogation in metastatic melanoma. Clin. Adv. Hematol. Oncol. 2010, 8, 259-266. [PubMed]

6. Chang, J. Cutaneous melanoma: Taiwan experience and literature review. Chang Gung Med. J. 2010, 33, 602-612. [PubMed]

7. Essner, R. Surgical treatment of malignant melanoma. Surg. Clin. 2003, 83, 109-156. [CrossRef]

8. Bleehen, N.; Newlands, E.; Lee, S.M.; Thatcher, N.; Selby, P.; Calvert, A.; Rustin, G.; Brampton, M.; Stevens, M. Cancer research campaign phase II trial of temozolomide in metastatic melanoma. J. Clin. Oncol. 1995, 13, 910-913. [CrossRef] [PubMed]

9. Treisman, J.; Garlie, N. Systemic therapy for cutaneous melanoma. Clin. Plast. Surg. 2010, 37, 127-146. [CrossRef] [PubMed]

10. Acquavella, N.; Kluger, H.; Rhee, J.; Farber, L.; Tara, H.; Ariyan, S.; Narayan, D.; Kelly, W.; Sznol, M. Toxicity and activity of a twice daily high-dose bolus interleukin 2 regimen in patients with metastatic melanoma and metastatic renal cell cancer. J. Immunother. 2008, 31, 569-576. [CrossRef] [PubMed] 
11. Ibrahim, N.; Haluska, F.G. Molecular pathogenesis of cutaneous melanocytic neoplasms. Annu. Rev. Pathol. Mech. Dis. 2009, 4, 551-579. [CrossRef] [PubMed]

12. Ng, P.L.; Rajab, N.F.; Then, S.M.; Yusof, Y.A.M.; Ngah, W.Z.W.; Pin, K.Y.; Looi, M.L. Piper betle leaf extract enhances the cytotoxicity effect of 5-fluorouracil in inhibiting the growth of HT29 and HCT116 colon cancer cells. J. Zhejiang Univ. Sci. B 2014, 15, 692-700. [CrossRef] [PubMed]

13. Rai, M.P.; Thilakchand, K.R.; Palatty, P.L.; Rao, P.; Rao, S.; Bhat, H.P.; Baliga, M.S. Piper betel Linn (betel vine), the maligned southeast asian medicinal plant possesses cancer preventive effects: Time to reconsider the wronged opinion. Asian Pac. J. Cancer Prev. 2011, 12, 2149-2156. [PubMed]

14. Venkadeswaran, K.; Muralidharan, A.R.; Annadurai, T.; Ruban, V.V.; Sundararajan, M.; Anandhi, R.; Thomas, P.A.; Geraldine, P. Antihypercholesterolemic and antioxidative potential of an extract of the plant, Piper betle, and its active constituent, eugenol, in triton WR-1339-induced hypercholesterolemia in experimental rats. Evid.-Based Complement. Altern. Med. 2014, 2014, 478973. [CrossRef] [PubMed]

15. Al-Adhroey, A.H.; Nor, Z.M.; Al-Mekhlafi, H.M.; Amran, A.A.; Mahmud, R. Antimalarial activity of methanolic leaf extract of Piper betle L. Molecules 2011, 16, 107-118. [CrossRef] [PubMed]

16. Toyota, M.; Saito, T.; Matsunami, J.; Asakawa, Y. A comparative study on three chmo-type of the liverwort conocephalum conicum using volatile constituents. Phytochemistry 1997, 44, 1265-1270. [CrossRef]

17. Haze, K.; Yoshida, H.; Yanagi, H.; Yura, T.; Mori, K. Mammalian transcription factor ATF6 is synthesized as a transmembrane protein and activated by proteolysis in response to endoplasmic reticulum stress. Mol. Biol. Cell 1999, 10, 3787-3799. [CrossRef] [PubMed]

18. Fusaro, G.; Dasgupta, P.; Rastogi, S.; Joshi, B.; Chellappan, S. Prohibitin induces the transcriptional activity of p53 and is exported from the nucleus upon apoptotic signaling. J. Biol. Chem. 2003, 278, 47853-47861. [CrossRef] [PubMed]

19. Nijtmans, L.G.; de Jong, L.; Sanz, M.A.; Coates, P.J.; Berden, J.A.; Back, J.W.; Muijsers, A.O.; van der Spek, H.; Grivell, L.A. Prohibitins act as a membrane-bound chaperone for the stabilization of mitochondrial proteins. EMBO J. 2000, 19, 2444-2451. [CrossRef] [PubMed]

20. Rajalingam, K.; Wunder, C.; Brinkmann, V.; Churin, Y.; Hekman, M.; Sievers, C.; Rapp, U.R.; Rudel, T. Prohibitin is required for ras-induced Raf-MEK-ERK activation and epithelial cell migration. Nat. Cell Biol. 2005, 7, 837-843. [CrossRef] [PubMed]

21. Winter, A.; Kämäräinen, O.; Hofmann, A. Molecular modeling of prohibitin domains. Proteins Struct. Funct. Bioinform. 2007, 68, 353-362. [CrossRef] [PubMed]

22. Wong, P.-F.; Cheong, W.-F.; Shu, M.-H.; Teh, C.-H.; Chan, K.-L.; AbuBakar, S. Eurycomanone suppresses expression of lung cancer cell tumor markers, prohibitin, annexin 1 and endoplasmic reticulum protein 28. Phytomedicine 2012, 19, 138-144. [CrossRef] [PubMed]

23. Yang, H.-B.; Song, W.; Chen, L.-Y.; Li, Q.-F.; Shi, S.-L.; Kong, H.-Y.; Chen, P. Differential expression and regulation of prohibitin during curcumin-induced apoptosis of immortalized human epidermal hacat cells. Int. J. Mol. Med. 2014, 33, 507-514. [CrossRef] [PubMed]

24. Liu, C.-I.; Wang, R.Y.-L.; Lin, J.-J.; Su, J.-H.; Chiu, C.-C.; Chen, J.-C.; Chen, J.Y.-F.; Wu, Y.-J. Proteomic profiling of the 11-dehydrosinulariolide-treated oral carcinoma cells Ca9-22: Effects on the cell apoptosis through mitochondrial-related and ER stress pathway. J. Proteom. 2012, 75, 5578-5589. [CrossRef] [PubMed]

25. Denicourt, C.; Dowdy, S.F. Targeting apoptotic pathways in cancer cells. Science 2004, 305, 1411-1413. [CrossRef] [PubMed]

26. Igney, F.H.; Krammer, P.H. Death and anti-death: Tumour resistance to apoptosis. Nat. Rev. Cancer 2002, 2, 277. [CrossRef] [PubMed]

27. Liao, C.-T.; Chang, J.T.-C.; Wang, H.-M.; Ng, S.-H.; Hsueh, C.; Lee, L.-Y.; Lin, C.-H.; Chen, I.-H.; Huang, S.-F.; Cheng, A.-J. Analysis of risk factors of predictive local tumor control in oral cavity cancer. Ann. Surg. Oncol. 2008, 15, 915-922. [CrossRef] [PubMed]

28. Nicholson, D.W.; Thornberry, N.A. Life and death decisions. Science 2003, 299, 214-215. [CrossRef] [PubMed]

29. Amarante-Mendes, G.P.; Kim, C.N.; Liu, L.; Huang, Y.; Perkins, C.L.; Green, D.R.; Bhalla, K. Bcr-abl exerts its antiapoptotic effect against diverse apoptotic stimuli through blockage of mitochondrial release of cytochrome $\mathrm{c}$ and activation of caspase-3. Blood 1998, 91, 1700-1705. [PubMed]

30. Rao, R.V.; Poksay, K.S.; Castro-Obregon, S.; Schilling, B.; Row, R.H.; del Rio, G.; Gibson, B.W.; Ellerby, H.M.; Bredesen, D.E. Molecular components of a cell death pathway activated by endoplasmic reticulum stress. J. Biol. Chem. 2004, 279, 177-187. [CrossRef] [PubMed] 
31. Kim, I.; Xu, W.; Reed, J.C. Cell death and endoplasmic reticulum stress: Disease relevance and therapeutic opportunities. Nat. Rev. Drug Discov. 2008, 7, 1013-1030. [CrossRef] [PubMed]

32. Xu, C.; Bailly-Maitre, B.; Reed, J.C. Endoplasmic reticulum stress: Cell life and death decisions. J. Clin. Investig. 2005, 115, 2656-2664. [CrossRef] [PubMed]

33. Boyce, M.; Yuan, J. Cellular response to endoplasmic reticulum stress: A matter of life or death. Cell Death Differ. 2006, 13, 363-373. [CrossRef] [PubMed]

34. Kouroku, Y.; Fujita, E.; Tanida, I.; Ueno, T.; Isoai, A.; Kumagai, H.; Ogawa, S.; Kaufman, R.; Kominami, E.; Momoi, T. ER stress (PERK/eIF2 $\alpha$ phosphorylation) mediates the polyglutamine-induced LC3 conversion, an essential step for autophagy formation. Cell Death Differ. 2007, 14, 230-239. [CrossRef] [PubMed]

35. Oyadomari, S.; Mori, M. Roles of CHOP/GADD153 in endoplasmic reticulum stress. Cell Death Differ. 2004, 11, 381-389. [CrossRef] [PubMed]

36. Ron, D.; Walter, P. Signal integration in the endoplasmic reticulum unfolded protein response. Nat. Rev. Mol. Cell Biol. 2007, 8, 519-529. [CrossRef] [PubMed]

37. Bollo, M.; Paredes, R.M.; Holstein, D.; Zheleznova, N.; Camacho, P.; Lechleiter, J.D. Calcineurin interacts with perk and dephosphorylates calnexin to relieve ER stress in mammals and frogs. PLoS ONE 2010, 5, e11925. [CrossRef] [PubMed]

38. Muller, C.; Bandemer, J.; Vindis, C.; Camaré, C.; Mucher, E.; Guéraud, F.; Larroque-Cardoso, P.; Bernis, C.; Auge, N.; Salvayre, R. Protein disulfide isomerase modification and inhibition contribute to ER stress and apoptosis induced by oxidized low density lipoproteins. Antioxid. Redox Signal. 2013, 18, 731-742. [CrossRef] [PubMed]

39. Teske, B.F.; Wek, S.A.; Bunpo, P.; Cundiff, J.K.; McClintick, J.N.; Anthony, T.G.; Wek, R.C. The eIF2 kinase PERK and the integrated stress response facilitate activation of ATF6 during endoplasmic reticulum stress. Mol. Biol. Cell 2011, 22, 4390-4405. [CrossRef] [PubMed]

40. Lin, Y.-H.; Chiu, J.-H. Use of chinese medicine among patients with liver cancer in taiwan. J. Altern. Complement. Med. 2010, 16, 527-528. [CrossRef] [PubMed]

41. Lin, J.-J.; Wang, R.Y.; Chen, J.-C.; Chiu, C.-C.; Liao, M.-H.; Wu, Y.-J. Cytotoxicity of 11-epi-sinulariolide acetate isolated from cultured soft corals on HA22T cells through the endoplasmic reticulum stress pathway and mitochondrial dysfunction. Int. J. Mol. Sci. 2016, 17, 1787. [CrossRef] [PubMed]

42. Wu, Y.-J.; Wong, B.-S.; Yea, S.-H.; Lu, C.-I.; Weng, S.-H. Sinularin induces apoptosis through mitochondria dysfunction and inactivation of the pi3k/akt/mtor pathway in gastric carcinoma cells. Mar. Drugs 2016, 14, 142. [CrossRef] [PubMed]

(C) 2018 by the authors. Licensee MDPI, Basel, Switzerland. This article is an open access article distributed under the terms and conditions of the Creative Commons Attribution (CC BY) license (http:/ / creativecommons.org/licenses/by/4.0/). 